\title{
LINGUOCULTURAL PROPERTIES OF PHRASEOLOGICAL UNITS
}

\author{
Sarvinoz Abbosjon Qizi Aliyeva
}

2nd Year Master's Degree Student, Fergana State University, Uzbekistan

\section{ABSTRACT}

The term phraseology was originally described in this article as a universal language unit, an important component that contributes to the diversity of a language's lexicon. However, it is illustrated by the fact that it belongs only to a specific ethnos, peoples, and some English and Uzbek phraseological expressions that express their national and cultural traits are evaluated and analyzed in addition to the international phraseological units. Such strong ties are a treasure that helps to preserve a country's national identity and heritage.

KEYWORDS: - Phraseological units, universality, connotative, cognitive, linguocreative, linguocultural, national-cultural features.

\section{INTRODUCTION}

The existence of phraseological units as a universal element in all languages of the world has been recognized by a number of leading scholars since the second half of the last century. The phraseological richness of languages in different systems was described in semantic, structural, and functional terms, and distinctive features were distinguished from other units in the language. In particular, it has been scientifically proven that they are an "linguistic phenomenon" with an independent linguistic unit and a complex semantic structure. Any language unit has not only a communicative function, but also a means of expressing the people, ethnicity, history of the people, way of life, national and cultural treasures that speak that language. In this case, the existing stable word combinations in languages are particularly noteworthy. Because most of them are "irrigated" with the main meaning, national and cultural identity.

Of course, every kind of art created by each nation, whether it is a painting, sculpture or national architecture, is of great importance in revealing the national characteristics of that nation. It should be noted that among these unique monuments, the scientific and practical value of the existing phraseological units of languages, folk proverbs, wise sayings is incomparable. The rare notions, feelings, and rules of morality among people, which have been refined and refined in the test of life through them, are not vividly, unimplemented, or comprehensively expressed through any other monuments. That is why the "treasure" of language is the treasure of the nation. The unique feelings expressed through language, the relationships in 
CURRENT RESEARCH JOURNAL OF PHILOLOGICAL SCIENCES 2(11):

135-140, November 2021

DOI: https://doi.org/10.37547/philological-crjps-02-11-29

ISSN 2767-3758

(C)2021 Master Journals

Crossref do

gil Google

Accepted $25^{\text {th }}$ November, 2021 \& Published $30^{\text {th }}$ November, 2021

the objective world, the values given to them are not fully realized by any other means. The role of language features in revealing the national and cultural world of the people, in reaching its foundations, in defining its peculiarities is invaluable.

The English have long kept a "pig" at home, and some of its features and actions are reflected in the expressions. For example, the phrase "eat like a pig" is used to describe a person who eats greedily and reluctantly. Another phrase associated with pork, "to buy a pig in a poke," literally translates to "buy a bag of pork." The reason for this phrase is that in the past, traders put only one pig on display, and put the rest in sacks. Some non-religious traders sold cat meat in those bags. Therefore, this phraseological combination is used in the sense that the purchase of something without a thorough examination leads to the purchase of something of poor quality. Also, "as sick as a pig" - a pig, sick, a pig is very upset when sick, caused the phrase "depression from something." This does not mean that the phraseological resources of any nation contain only the words "molded" or "wrapped" with national and cultural features. It should be noted that, despite the fact that peoples are far from each other, belong to different religions and have their own culture, there are phraseological expressions that have the exact equivalent of both form and content.

We cite the following examples as proof of our point.

1. as sly as a fox - cunning as a fox - as cunning as a fox;

2. the seven wonders of the world- sem chudes sveta - the seven wonders of the world;

3. no rose without a thorn - net rozy bez shipova rose without thorns;

4. you reap what you sow- chto poseesh, to i pojnyoshy - ekaningni orasan;

5. odna golova khorosho, a dve luchshe- two heads are better than one- one head is better, two are better;

6. china wall - kitayskaya stena - Chinese wall

7. window to the world - okno v mir

After all, the linguistic landscape of the world is historically formed in each language. The natural world in which any language community lives is reflected in its language and is passed down from generation to generation.

It should be noted that the formation of the scale of phraseological meaning is a very complex process and depends on a number of parameters. The lexical units involved in the phraseological expression are involved differently in the formation of a unique phraseological meaning. People create short, broad units of meaning in order to name and express new concepts or to reveal different aspects of existing concepts. These are, of course, phraseological expressions that have been understood by the people for many years. These units not only name something in the language in a simple way, but also evaluate its connotativestylistic coloring, the attitude of the person to existence. Therefore, when phraseological meaning is compared with lexical meaning, it shows its originality. The diversity of meanings in phraseological expressions and their ready use should also be recognized as a "treasure" that preserves the traditions that have long been forgotten. They not only provide an introduction to the national worldview, but also to the worldview left in the history of nations. Through linguocreative thinking, using existing meanings in the language, phraseological expressions specific to this ethnos are formed. In this process, first of all, a simple meaning-generating ("generating") mechanism is activated, that is, after the use of apology-like migration methods, they are joined by a convergent-devergent process, and therefore they The linguistic landscape of the world is the most important means of expressing the national and cultural mentality of a particular nation. According to the great linguist V. Humboldt, "each language" has its own internal appearance, form, "spirit" of 
CURRENT RESEARCH JOURNAL OF PHILOLOGICAL SCIENCES 2(11):

135-140, November 2021

DOI: https://doi.org/10.37547/philological-crjps-02-11-29

ISSN 2767-3758

(C)2021 Master Journals

\section{Crossref do}

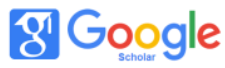

Accepted25 $5^{\text {th }}$ November, 2021 \& Published $30^{\text {th }}$ November, 2021

the people, having a voluntary way of "own will" in the formation of a new element of thought. associated with ". His unique ideas in the context of his language, my language, my soul, my language are remarkable.

Of course, phraseological units play an important role in revealing the ethno-cultural content of any nation, ethnic group, and in penetrating deeper into them. Let us pay attention to the examples of different landscapes of the world with the emergence of a number of voluntary associative connections through ethnocultural consciousness: 1.Phraseological units formed with the participation of national costumes: In Uzbek: The meaning of "fikri o'zgarib qolishlik" is expressed by “To'nini teskari kiymoq". Or the word "doppi" in the phraseological phrase "throwing the doppi into the sky" is formed by the Uzbek national headdress meaning "to be happy". Another phrase used in the phrase "etagingni yigishtirib ol" is "etak", which is a wide part of the bottom of a women's shirt. However, the phrase is also used for men. The phraseological meaning is used in the sense of "vaqtida biron shni to'xtatishlik".

Phraseologisms expressed in clothes are also common in English. To cite a few examples, "To have a bee in one's bonnet" literally means "bee in a hat," and bonnet used to refer to small hats worn by women and has survived as an idiom. It is mainly used for women and means "indulging in an idea". It's easy to imagine how this phrase came about: bees falling into a hat make anyone nervous. "Wear the pants" - in history, women's clothing was considered only shirts and skirts, and pants were mainly men's clothing. Women's wearing of trousers has given rise to the phrase "who is the master or the boss in the house" . For the English nation, the "glove" has long been a national costume, and associated phrases have emerged. One of them, "Hand in glove with someone" The origin of this idiom is intuitively clear - "hands in one glove", that is, to be in close contact with someone. Or another, "throw down the gauntlet" which now means to oppose or oppose someone, but previously the phrase was not a metaphor, that is, a heavy, armored glove of knights - "gauntlet", calling the enemy to a duel by shooting.

2. Phraseologisms associated with national traditions: In the Uzbek mentality, we encounter many traditions associated with weddings, and they are reflected in a number of phraseologies. The proverb "kelinni ko'rganda ko'r, sepini yoyganda" is related to the custom of "sep yoydi", which is mainly typical of the valleys and was previously sewn by the brides with their own hands to show their mastery. embroidery, dresses, handkerchiefs "spread" the groom in the house .

The English also have wedding traditions, for example, the phrase "dance attendance on somebody" is an old custom, the bride dances with each wedding guest originated through the fall, and it means to wait carefully and cautiously, to fulfill someone's wish or whim. "Get the wooden spoon" get a wooden spoon. According to the custom of the University of Cambridge, whoever gets the lowest score in the math exam, is rewarded with a wooden spoon, and the phrase "to be the last in the competition or to be the worst" appeared in the language. For Uzbeks, "bread" is the most valuable food, and it is reflected in the phraseology. In the phrase "breaking bread" we can see how much bread is valued, that is, for the people it is considered the "head of goodness", and according to our traditions, this phrase is used to engage the bride and groom before the wedding. A similar custom exists among the English. In them, "salt" is a valuable food, so it is valued and is clearly visible in the phrase "above the salt." Salt is always placed in the middle of the table, and whoever is moved "above the salt" is ranked higher.

3. Phraseologisms related to national dishes: We 
CURRENT RESEARCH JOURNAL OF PHILOLOGICAL SCIENCES 2(11):

135-140, November 2021

DOI: https://doi.org/10.37547/philological-crjps-02-11-29

ISSN 2767-3758

(C)2021 Master Journals

Crossref doi

gil Google

Accepted25 $5^{\text {th }}$ November, 2021 \& Published $30^{\text {th }}$ November, 2021

can also see the names of national dishes in phraseological units. The phrase "atala", which is typical for the Uzbek people, gave rise to the phrase "ataladan suyak chiqmoq." In other words, because atala is a liquid, light food, it is made of bone, it is unpleasant, absurd, and the same meaning is transferred to the phrase. As another example, if we analyze the phrase "moshxo'rdaga qatiq bo'lmoq" the food in "moshxo'rda" does not "say" along with yoghurt, and this situation also means that "something, someone or event is superfluous" in the phrase. If we continue the examples, we will mention the phrase "chuchvarani xom sanamoq". "Chuchvara" is a meat dish made of dough, which has the phraseological meaning of counting it raw and imagining it raw. The food eaten by Uzbeks at weddings is pilaf, and it is associated with goodness and phrases such as "yaxshi odamosh ustiga."

Pudding, a favorite dish of the British, can also be seen in the following phrase. "To overegg the pudding" - although the verb over-egg is not found in dictionaries, it is not difficult to understand its meaning, which means "to put more eggs in the pudding". Excessive sweetness spoils its taste, which means "exaggeration". Eggs are another English dish used in the preparation of omelets pancakes, and is reflected in the article "You can not make an omelet without breaking (a few) eggs." Literally translated "you can't make an omelet without an egg" and sometimes it means that you have to do unpleasant things to perform a task or achieve a goal.

4. Stable compounds associated with the names of fruits and vegetables: We can see that one of the melons comes in the phraseology "watermelon", the phrase "tarvuzi qo'ltigidan tushmoq" Uzbeks usually picked watermelon under the armpit and its fall, its despair, its looseness, its sadness, has a phraseological meaning. Another "qovun tushirmoq", "melon", is also associated with laughter and humor, and the phrase "melon" comes from the phrase "biror ishni pachavasini chiqarmoq."

"To compare apples and oranges" in English means "comparing apples and oranges". "Ginger shall be hot in the mouth" - ginger should be warm in the mouth. Ginger is a common vegetable in the British diet, and its bitter taste in the mouth, inviting people to pleasure, has a phraseological meaning. "To pass an olive branch" - "to give an olive branch". Giving an olive branch meant peace, and the phrase is used to reconcile someone.

5. Phraseologisms associated with the names of geographical places:

The phrase "Asakasi ketmoq", which is found in the Uzbek colloquial language, is used for jealous people, Asaka is a district in Andijan region. Also, in the phraseological unit, which means to see and punish his mother Uchkurgan, Uchkurgan district is a place unique to the Uzbek nation. The phrase "Ahmoqqa quva bir tosh" also means "Kuva" is a district in the Fergana region, and to a foolish person, a place like Kuva means nothing.

The phrase "to carry coal to Newcastle" dates back to 1,500 years. At that time, Newcastle was the largest coal mining center, which meant that it was useless to import coal there. Also, the phrase "to go back to Civvy Street" means "return to civilian life after serving in the armed forces." "Meet one's Waterloo" refers to a battle outside Waterloo, Belgium in 1815, in which Napoleon Bonaparte was defeated by forces under the Duke of Wellington, and the term Waterloo was used to describe anything that was difficult to master quickly. has become synonymous with "to set the Thames on $\mathrm{fi}$ re" - "to set on the Thames" was widely used in the late 18th century and has always been used as a mockery to describe a simple-minded or nonbusiness person. Sending someone to a Coventry prison for neglect or exclusion made the English phrase "to send to Coventry" apydo. That is, around 1648, Cromwell sent a number of royal soldiers to prison in Coventry, and the locals, who were 
CURRENT RESEARCH JOURNAL OF PHILOLOGICAL SCIENCES 2(11):

135-140, November 2021

DOI: https://doi.org/10.37547/philological-crjps-02-11-29

ISSN 2767-3758

(C2021 Master Journals

Crossref do:

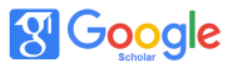

Accepted $25^{\text {th }}$ November, 2021 \& Published $30^{\text {th }}$ November, 2021

supporters of the parliament, bypassed them and refused to join them.

\section{Phraseological idioms related to national} holidays

Putting henna after hayt - Uzbeks, one of the religious holidays, say that women put henna on their hands to make them beautiful, and that it is not necessary to put henna after hayit. to do. "At last Lammas" - formerly Lammas Day, was celebrated on August 1 as a harvest festival, and "the last Lammas" meant never getting paid. It means never now.

\section{Phraseologisms related to religious concepts}

Due to the fact that the English people belong to the Christian religion, there are phraseological expressions associated with baptism in the language. For example, the term "baptism of fire" refers to the grace of the Holy Spirit given by true martyrdom by fire or by Christian baptism, and the phrase implies difficulty or martyrdom. The English proverb "the friar preached against stealing and had a goose in his sleeve" means that a monk preaches against stealing but has a goose in his sleeve. In Uzbek, the phrase "Havzi Kavsarni o'ylamoq", according to religious legends, "Havzi Kavsar" is the spring of Paradise, the water given by angels. The fact that the confirmation of the existence or non-existence of something depends on the will of Allah is expressed in the Uzbek language by the phrase "valloxu alam- Allah knows best." [5] Also, the term "Asfalasofilin - the bottom of hell, hell" also means "to become asfalasofilin" to perish.

\section{Conclusion}

In conclusion, phraseological units are universal linguistic units and are present in all languages. This unique linguistic unit in linguistics plays an important role in increasing the vocabulary of the language. Phraseological units in languages also perform not only nominative functions, but also cognitive, connotative functions. Most phraseological units have a national-cultural character and represent the historical, national, cultural treasures of any language.

\section{REFERENCES}

1. Виноградов В. В. Основные типы фразеологических единиц в русском языке. -М., 1947

2. Гумболт В. Избранные труды по языкознанию М. 1984. 103с

3. Free dictionary.com

4. Кунин А. В. Английская фразеология /теоретический курс. - М., 1970.

5. Umarxo ja E.M. diniy atamalar va iboralar Toshkent, 2016, 219 bet

6. Чернышева “Актуальные проблемы фразеологии" В N5 1977"

7. Амосова Н.Н. Значение фразеологии как особой отрасли языкознания - Вологда, 1967

8. Rahmatullayev Sh. O`zbek tilining izohli frazeologik lug`ati - Toshkent, 1978, 405 bet

9. Бабкин А.М. Русская фразеология, ее развитие, источники и лексикографическая разработка Автореферат дис. на соискание учен. степени д-ра филол. наук. (660) Ленинград, 1967.

10. Ismatullayeva, N. R. Translation of phraseological units in Chinese and Uzbek languages. In Scientific research of the SCO countries: synergy and integration (International conference). Beijing, PRC, June (Vol. 24, pp. 45-50).

11. Рахматуллаев Ш.У. Основные грамматические особенности образных глагольных фразеологических единиц 
CURRENT RESEARCH JOURNAL OF PHILOLOGICAL SCIENCES 2(11):

135-140, November 2021

DOI: https://doi.org/10.37547/philological-crjps-02-11-29

ISSN 2767-3758

(C)2021 Master Journals

7 Crossref dol 81 Google

Accepted25th November, 2021 \& Published 30th November, 2021

современного узбекского языка. АКД. - М.:

1952. 